\title{
DINAMIKA PSIKOLOGIS PEMBENTUKAN PARENTING SELF EFFICACY PADA ORANGTUA PENYANDANG TUNARUNGU YANG MEMILIKI ANAK BERPENDENGARAN NORMAL
}

\author{
Dewi Ilma Antawati dan Hetty Murdiyani \\ Program Studi Psikologi Universitas Muhammadiyah Surabaya
}

\begin{abstract}
Parenting self efficacy as a cognitive part of parenting competence has emerge as a salient predictor of positive parenting practice and as a mediator effect of many parenting qualities, including parental depression and child temperament. Unfortunately, there are limited research focused on the analysis of psychological dynamic that explain the process of parenting self efficacy, especially in parents with hearing impairment who has limited access and social support related to child rearing. The aim of this study was to uncover the factors that form parent beliefs about their capabilities to perform child rearing. Seventeen parents with hearing impairment fill out the PSE questionnaire to see the estimation of their PSE degree. The result has discover that 5 of them have low level of PSE and 12 of them are in the middle level.
\end{abstract}

Keywords: Parenting self efficacy, parenting, hearing impairment.

\begin{abstract}
Abstrak: Parenting self efficacy sebagai bagian dari faktor kognitif kompetensi pengasuhan telah diyakini sebagai prediktor yang jelas dari praktek pengasuhan yang positif dan efek mediator dari berbagai kualitas pengasuhan, termasuk depresi orangtua, dan temperamen anak. Namun belum banyak penelitian yang dilakukan untuk menganalisis bagaimana dinamika psikologis pembentukan aspek tersebut, terutama pada orangtua penyandang tunarungu yang memiliki keterbatasan akses informasi dan dukungan sosial dalam pengasuhan anak. Tujuan dari penelitian ini adalah mengungkap faktor-faktor yang membentuk keyakinan orangtua penyandang tunarungu akan kemampuannya dalam melakukan pengasuhan anak. Tujuhbelas orangtua tunarungu mengisi kuesioner untuk mengungkap tingkat parenting self efficacy subjek. Hasilnya 5 orang memiliki tingkat PSE dengan kategori rendah, dan 12 orang memiliki tingkat PSE dengan kategori sedang.
\end{abstract}

Kata kunci: Parenting self efficacy, pengasuhan, anak tunarungu.

Orangtua adalah pendidik pertama dan utama bagi anak. Sejak bayi masih ada dalam kandungan, orangtualah yang memberikan pendidikan pertama pada anak berupa stimulasi dini yang dapat merangsang pertumbuhan otak janinnya. Ketika anak lahir, orangtua pulalah yang pertama kali memberikan pendidikan awal pada anaknya. Ayah dan ibu memiliki peran yang berbeda dalam pendidikan anak. Ibu lebih banyak berhubungan dengan afeksi dan perkembangan bahasa, sedangkan ayah lebih banyak berhubungan dengan aktivitas fisik dan motivasional. Salah satu peran orangtua adalah menumbuhkan perasaan mencintai dan mengasihi pada anak melalui interaksi yang melibatkan sentuhan fisik dan kasih sayang. Agar dapat mewujudkan hal tersebut, tentunya orangtua harus memiliki persepsi positif terhadap anak dan dirinya sendiri sehingga dapat mengasihi dan mencintai anaknya dengan tulus, dan pada gilirannya orangtua dapat mengajarkan cinta kasih yang tulus tersebut pada anak, dan anak menjadi individu yang juga dapat mencintai dan mengasihi orang lain dengan tulus. 
Salah satu faktor yang berpengaruh terhadap perilaku pengasuhan yang dilakukan oleh orangtua adalah parenting self efficacy yang didefinisikan sebagai persepsi orangtua terhadap kemampuan mereka dalam mempengaruhi perilaku dan perkembangan anak secara positif. Dari berbagai penelitian ditemukan bahwa parenting self efficacy yang tinggi berkaitan erat dengan kapasitas orangtua untuk menyediakan lingkungan pengasuhan anak yang adaptif, menstimulasi, dan mendorong perkembangan anak. Sebaliknya, parenting self efficacy yang rendah berhubungan dengan depresi yang dialami orangtua, perilaku defensif dan mengontrol, kemunculan gangguan perilaku pada anak, persepsi orangtua bahwa anak memiliki perilaku yang sulit, stress, dan gaya coping yang pasif. Parenting self efficacy yang rendah juga berkaitan dengan kecenderungan orangtua untuk fokus pada kesulitan dalam hubungan antara suami dan istri, afeksi yang negatif, tingkat stress yang meningkat, perasaan tidak berdaya dalam peran sebagai orangtua, dan penggunaan teknik pendisiplinan dengan hukuman (Coleman \& Karraker, 2000).

Self efficacy didefinisikan sebagai keyakinan seseorang tentang kemampuan yang dimilikinya dalam mengarahkan performansinya yang kemudian berpengaruh terhadap berbagai kejadian dalam kehidupan mereka (Bandura, 1994). Self efficacy tidak hanya memiliki pengaruh langsung terhadap pemilihan aktivitas dan settingnya, namun melalui harapan terhadap keberhasilan, efficacy dapat mempengaruhi usaha coping yang dilakukan seseorang. Efficacy expectation menunjukkan seberapa besar usaha yang akan dilakukan seseorang dan berapa lama mereka akan bertahan ketika mereka mengalami hambatan atau pengalaman yang tidak menyenangkan. Semakin kuat self efficacy, maka usaha yang dilakukan akan semakin aktif. Individu yang bertahan dalam aktivitas yang secara subjektif mengancam bagi dirinya, meskipun kenyataannya relatif aman, akan memperoleh pengalaman yang meningkatkan efficacy mereka, sehingga akan menghilangkan perilaku defensifnya. Sebaliknya mereka yang meragukan usahanya sendiri ketika baru memulainya, akan kehilangan harapan positif dan mengalami ketakutan dalam waktu yang relatiflama (Bandura, 1977).

\section{Parenting selfefficacy}

Parenting self efficacy merupakan salah satu bagian dari aspek kognitif dalam kompetensi pengasuhan. Parenting self efficacy (PSE) didefinisikan sebagai perkiraan orangtua terhadap kompetensi yang dimilikinya dalam perannya sebagai orangtua, atau persepsi orangtua terhadap kemampuannya untuk mempengaruhi perilaku dan perkembangan anak secara positif (Coleman \& Karraker, 2000). PSE yang tinggi berhubungan erat dengan kapasitas orangtua dalam menyediakan lingkungan pengasuhan yang adaptif, menstimulasi, dan mendorong perkembangan (Donovan, Leavitt, \& Walsh, 1997).

Berdasarkan teori belajar sosial dari Bandura (dalam Coleman, 1998), proses pembentukan PSE dipengaruhi empat hal, yaitu pengalaman keberhasilan yang pernah dialami oleh individu (direct experience), pengalaman mengamati orang lain melakukan sesuatu (vicarious experience), umpan balik verbal dari orang lain (verbal persuasion), dan kondisi emosi (emotional state). Maddux (2002, dalam Harty, 2009) menambahkan faktor ke lima, yaitu pengalaman imagery, yaitu bayangan diri sendiri mengalami keberhasilan dalam melakukan sesuatu.

Pembentukan PSE tidak terjadi secara otomatis, melainkan melalui suatu proses penilaian. Menurut Harty (2009) tiga proses yang utama adalah observasi diri, proses 
penilaian dan reaksi diri. Setiap komponen tersebut memberi sumbangan pada pembentukan perilaku. Menurut Bandura (1994), observasi diri tidak hanya memberikan informasi penting dalam menetapkan standar perilaku yang realistik, tetapi juga menjadi proses koreksi yang berujung pada perubahan perilaku. Observasi diri semata hanya memberikan sedikit informasi sebagai dasar individu bereaksi. Proses memberikan makna pada perilaku (berdasarkan standar pribadi ataupun standar lain yang penting bagi individu) menjadi dasar pembentukan reaksi. Ini kemudian yang menjadi rangkaian proses ke dua. Proses penilaian ini menyaring perilaku dan membentuk dasar penilaian perilaku sebagai berhasil atau tidak. Saringan ini dipengaruhi oleh norma dan nilai budaya, dan konteks sosial dimana perilaku terjadi. Komponen akhir adalah reaksi diri, yaitu reaksi terhadap perilaku seseorang, yang bergantung pada penilaian berdasarkan standar internal. Dengan demikian, individu melakukan tindakan yang menghasilkan reaksi diri positif dan menghindari perilaku yang menimbulkan penilaian buruk terhadap diri sendiri (self censure).

Self efficacy sangat penting dalam keberfungsian individu karena mempengaruhi emosi, pikiran, motivasi, dan perilaku. Berkaitan dengan PSE, Bandura (1994) menyatakan bahwa individu yang memiliki tingkat PSE tinggi mampu membimbing anak-anak mereka melalui tahapan perkembangan yang dihadapi tanpa permasalahan yang serius atau tegangan dalam hubungan mereka dengan pasangannya. Individu yang memiliki PSE rendah harus berjuang keras untuk memenuhi tuntutan dalam keluarga sehingga beresiko mengalami stress dan depresi (Sanders \& Woolley, 2005).

Berbagai penelitian (Donovan dkk, 1990; Teti \& Gelfand, 1996; Wells-Parker dkk, 1990, dalam Harty, 2009) membuktikan bahwa PSE memberikan dampak pada berbagai level dalam ekologi keluarga. Dalam level mikrosistem, PSE berdampak pada faktor personal lain. Tingkat PSE yang tinggi berhubungan dengan kepuasan pengasuhan yang tinggi dan tingkat depresi yang rendah. PSE juga mempengaruhi faktor lain seperti persepsi terhadap stress dan cara coping yang digunakan orangtua untuk menghindari stress. Berbagai studi (Coleman \& Karraker, 1998; Scheel \& Rieckmann, 1998; Teti \& Gelfand, 1991; Wells-Parker, dkk, 1990 dalam Harty, 2009) telah dilakukan untuk meneliti peran self efficacy dalam memprediksi praktek pengasuhan. Hasil penelitian tersebut menyatakan bahwa peningkatan level PSE akan mengurangi persepsi adanya kesulitan dalam mengasuh anak, dan menghasilkan praktek pengasuhan yang positif.

Menurut Shahan (2003), dalam hal pemeliharaan anak orangtua memiliki tanggungjawab untuk mengatur, membesarkan, dan menyejahterakan anak serta menjadi sumber dari kesenangan, kepuasan, dan prestasi anak. Sementara itu Berns (dalam Bigner, 1994) mengatakan bahwa dalam pengasuhan orangtua juga mengajarkan anak untuk bersosialisasi, dimana orangtua mengajari anak pengetahuan, keterampilan, dan pembentukan sifat karakter yang dapat membuat anak tumbuh menjadi pribadi yang lebih efektif dan dapat berfungsi seutuhnya. Selain itu pengasuhan juga dipandang sebagai sebuah proses sosialisasi dari orangtua dalam mempengaruhi anak-anaknya agar dapat berperilaku sesuai dengan lingkungan sosial berdasarkan keyakinan, nilai-nilai dan pandangan atas harapan sosial dari orangtua sendiri. Namun pengasuhan bukan sematamata proses satu arah yang dilakukan orangtua terhadap anak, melainkan sebuah transaksi antara orangtua dan anak (Jacobson, 2004). 


\section{Pengasuhan}

Terdapat beberapa aspek yang berkaitan dengan pengasuhan (Bornstein, 1998), yaitu :

a. Nurturant caregiving

Aspek ini meliputi pemenuhan kebutuhan anak secara fisik. Orangtua bertanggungjawab menjaga anak-anak mereka dengan baik dan mencegah anak dari bahaya sakit. Orangtua memiliki tugas untuk merawat anak sejak bayi seperti menyediakan makanan, merawat anak secara rutin, menjaga dan mengawasi anak, serta memberikan kenyamanan pada anak. Perawatan nurturance ini sangat berkaitan dengan daya tahan (survival) serta kesejahteraan (well-being) anak.

b. Material caregiving

Aspek ini meliputi cara orangtua mengawasi, mengorganisir, dan mengatur lingkungan fisik anak seperti rumah dan lingkungan sekitarnya. Orangtua memiliki tanggungjawab menyediakan obyekobyek stimulasi seperti mainan, buku, atau peralatan keseharian lain. Orang tua juga perlu memberikan batasan kebebasan fisik bagi anak dan memberikan keamanan serta dimensi-dimensi fisik yang berkaitan dengan pengalaman yang dapat diperoleh anak. Hal ini termasuk pula penyediaan waktu bagi anak untuk bermain dengan obyek maupun berinteraksi dengan orang di sekitarnya.

c. Social caregiving

Aspek ini meliputi perilaku orangtua dalam membangun keterikatan emosional dan mengatur interaksi timbal balik antara orangtua dengan anak. Perilaku dapat berupa sentuhan fisik, tatapan mata, tutur kata, maupun senyuman. Melalui tanggapan yang positif, keterbukaan, negosiasi, mendengar aktif, dan kedekatan emosional, orangtua dapat membuat anak merasa lebih berharga, lebih dihargai dan merasa diterima dalam lingkungannya.
Pengasuhan ini juga meliputi dukungan orangtua untuk membantu anak mengatur perilaku dan emosinya, cara berkomunikasi dan juga membantu anak membangun hubungan interpersonal yang bermakna dalam waktu yang berkepanjangan.

d. Didactic caregiving

Aspek ini meliputi beragam strategi yang digunakan orangtua untuk memberikan stimulasi pada anak dan memahami serta mempelajari hal-hal yang terjadi di lingkungan sekitar. Didaktik berarti memperkenalkan, menghubungkan dan mengartikan dunia luar anak. Selain itu di dalam didaktik juga tercakup proses mendidik, menjelaskan dan memberi contoh pada anak. Orangtua memberikan kesempatan bagi anak untuk mengamati, meniru, dan mempelajari dunia luarnya sendiri, namun tetap dengan pengawasan orangtuanya.

\section{Tuna Rungu}

Tunarungu adalah individu yang kehilangan seluruh atau sebagian daya pendengarannya sehingga tidak atau kurang mampu berkomunikasi secara verbal dan walaupun telah diberikan pertolongan dengan alat bantu dengar masih tetap memerlukan pelayanan pendidikan khusus. Seseorang dikatakan sebagai tunarungu jika memenuhi minimal enam diantara ciri-ciri berikut (Direktorat Pendidikan Luar Biasa Departemen Pendidikan Nasional, 2004): a) Secara nyata tidak mampu mendengar; b) Terlambat perkembangan bahasanya; c) Sering menggunakan isyarat dalam berkomunikasi; d) Kurang/tidak tanggap bila diajak bicara; e) Ucapan kata tidak jelas; f) Kualitas suara aneh/monoton; g) Sering memiringkan kepala dalam usaha mendengar; h) Banyak perhatian terhadap getaran; i) Keluar cairan "nanah" dari kedua telinga. 


\section{METODE}

Penelitian ini menggunakan pendekatan kualitatif, dengan menggunakan survei, wawancara dan observasi.

\section{Partisipan}

Subjek sebagai informan kunci dalam penelitian ini adalah orangtua tunarungu yang memiliki anak berpendengaran normal dengan usia 5-12 tahun. Semua subjek berdomisili di Surabaya dan merupakan peserta pengajian tuna rungu di sebuah Masjid di Surabaya yang diselenggarakan setiap hari Minggu. Karakteristik tersebut dipilih karena pada usia 5-12 tahun anak memiliki tugas perkembangan yang berkaitan dengan dasardasar kemampuan akademik dan kompetensi sosial yang bernilai di masyarakat. Pada usia tersebut anak masih bergantung sepenuhnya pada orangtua, sehingga orangtua memiliki posisi sebagai pembimbing anak untuk menjalani tugas perkembangannya, dan perlu memiliki pengalaman, pengetahuan, dan keterampilan, yang dipadukan dengan pemahaman tentang sifat dan kebutuhan anak. Selain itu peneliti juga menetapkan dua orang pembina dan guru pengajian tuna rungu sebagai informan biasa.

\section{Teknik Pengumpulan data}

Untuk mengetahui tingkat parenting self efficacy (PSE), para calon subjek diminta mengisi kuesioner PSE yang diadaptasi dari kuesioner P-SEMI (Parenting Self Efficacy Measuring Instrument) dari Harty (2009). Dari total 24 orang yang ditawari untuk mengisi kuesioner, diperoleh 17 orang subjek yang mengisi dan mengembalikan kuesioner. Lima (5) subjek dari 17 orang yang mengisi kuesioner berhasil direkrut oleh peneliti untuk diwawancarai secara mendalam. Empat subjek memiliki tingkat PSE sedang ( $\mathrm{Pi}, \mathrm{NF}$,
Dar, TUH) dan seorang subjek memiliki tingkat PSE rendah (NDM). Observasi juga dilakukan pada subjek Pi, NF, Dar, dan NDM. Proses wawancara dibantu oleh penerjemah bahasa tunarungu.

\section{Teknik Analisis Data}

Analisis data penelitian dilakukan dengan strategi deskriptif kualitatif dengan teknik patttern matching dan explanation building. Data hasil wawancara yang diperoleh dari responden, disajikan dalam bentuk tabel yang memuat pertanyaan beserta jawaban-jawaban responden. Kemudian dilakukan pencocokan pola dengan membandingkan antara pola-pola yang diperoleh secara empirik dari data dengan pola-pola yang diprediksikan dari literatur. Langkah terakhir adalah membangun penjelasan dari kasus yang diteliti untuk menyusun dinamika psikologis subjek.

\section{HASIL}

Setelah subjek mengisi kuesioner, maka dilakukan analisis data untuk melihat tingkat PSE yang dimiliki subjek. Tingkat PSE dibagi menjadi lima kategori, yaitu tinggi sekali, tinggi, sedang, rendah, dan rendah sekali. Dari kuesioner yang terkumpul sementara diperoleh hasil 5 orang memiliki tingkat PSE pada kategori rendah, dan 12 orang memiliki tingkat PSE pada kategori sedang. Berikut hasil tabulasi silang tingkat PSE dengan variabel jenis kelamin, pendidikan, penghasilan, status pernikahan, dan usia orangtua: 
PSE* JENIS KELAMIN Crosstabulation

\begin{tabular}{lllrrr}
\hline & & \multicolumn{2}{c}{ JENIS KELAMIN } & \\
\cline { 3 - 4 } & & laki laki & perempuan & \multicolumn{2}{c}{ Total } \\
\hline PSE & rendah & Count & 4 & 1 & 5 \\
& & $\%$ of Total & $23,5 \%$ & $5,9 \%$ & $29,4 \%$ \\
\cline { 2 - 5 } & \multirow{2}{*}{ sedang } & Count & 6 & 6 & 12 \\
& & $\%$ of Total & $35,3 \%$ & $35,3 \%$ & $70,6 \%$ \\
\hline Total & Count & 10 & 7 & 17 \\
& & $\%$ of Total & $58,8 \%$ & $41,2 \%$ & $100,0 \%$ \\
\hline
\end{tabular}

PSE* PENDIDIKAN Crosstabulation

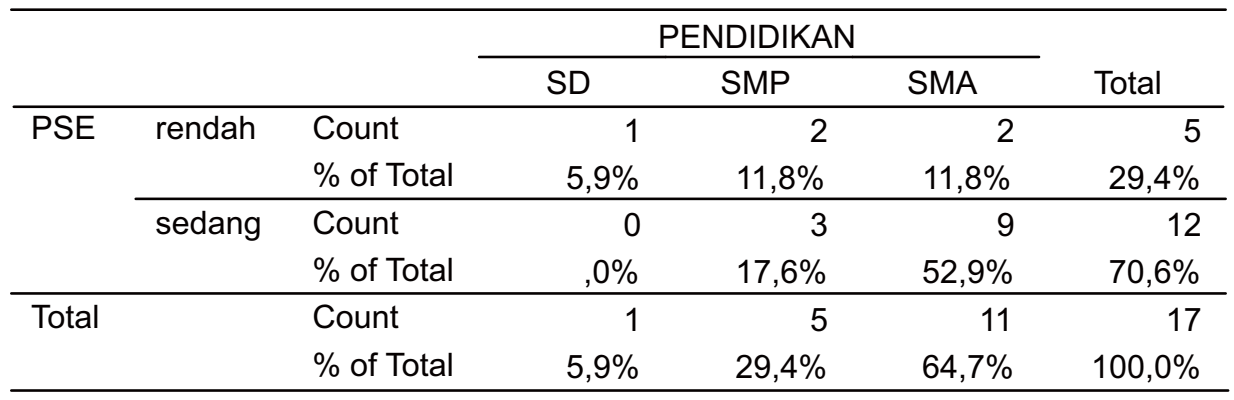

\begin{tabular}{|c|c|c|c|c|c|}
\hline \multicolumn{6}{|c|}{ PSE* PENGHASILAN Crosstabulation } \\
\hline & & & \multicolumn{2}{|c|}{ PENGHASILAN } & \multirow[b]{2}{*}{ Total } \\
\hline & & & $>1000000$ & $\begin{array}{l}1000000- \\
2000000\end{array}$ & \\
\hline \multirow[t]{4}{*}{ PSE } & rendah & Count & 3 & 2 & 5 \\
\hline & & $\%$ of Total & $17,6 \%$ & $11,8 \%$ & $29,4 \%$ \\
\hline & sedang & Count & 4 & 8 & 12 \\
\hline & & $\%$ of Total & $23,5 \%$ & $47,1 \%$ & $70,6 \%$ \\
\hline \multirow[t]{2}{*}{ Total } & & Count & 7 & 10 & 17 \\
\hline & & $\%$ of Total & $41,2 \%$ & $58,8 \%$ & $100,0 \%$ \\
\hline \multicolumn{6}{|c|}{ PSE * PERNIKAHAN Crosstabulation } \\
\hline & & & \multicolumn{2}{|c|}{ PERNIKAHAN } & \\
\hline & & & menikah & tidak menikah & Total \\
\hline \multirow[t]{4}{*}{ PSE } & rendah & Count & 3 & 2 & 5 \\
\hline & & $\%$ of Total & $17,6 \%$ & $11,8 \%$ & $29,4 \%$ \\
\hline & sedang & Count & 12 & 0 & 12 \\
\hline & & $\%$ of Total & $70,6 \%$ &, $0 \%$ & $70,6 \%$ \\
\hline \multirow[t]{2}{*}{ Total } & & Count & 15 & 2 & 17 \\
\hline & & $\%$ of Total & $88,2 \%$ & $11,8 \%$ & $100,0 \%$ \\
\hline
\end{tabular}

Dari hasil tabulasi silang tersebut dapat dilihat lebih jelas kondisi PSE yang dimiliki subjek. Subjek yang memiliki PSE rendah 75\% berjenis kelamin laki-laki dan 25\% berjenis kelamin perempuan, sedangkan untuk subjek dengan tingkat PSE sedang 50\% berjenis kelamin laki-laki dan sisanya berjenis kelamin perempuan. Kemudian berdasarkan tingkat pendidikan, perbedaan yang mencolok tampak pada subjek yang memiliki PSE sedang. 
PSE * USIA Crosstabulation

\begin{tabular}{|c|c|c|c|c|c|c|c|}
\hline & & & \multicolumn{4}{|c|}{ USIA } & \multirow[b]{2}{*}{ Total } \\
\hline & & & $25-30$ & $31-35$ & $36-40$ & $45<$ & \\
\hline \multirow[t]{4}{*}{ PSE } & rendah & Count & 0 & 2 & 3 & 0 & 5 \\
\hline & & $\%$ of Total &, $0 \%$ & $11,8 \%$ & $17,6 \%$ &, $0 \%$ & $29,4 \%$ \\
\hline & sedang & Count & 3 & 6 & 2 & 1 & 12 \\
\hline & & $\%$ of Total & $17,6 \%$ & $35,3 \%$ & $11,8 \%$ & $5,9 \%$ & $70,6 \%$ \\
\hline \multirow[t]{2}{*}{ Total } & & Count & 3 & 8 & 5 & 1 & 17 \\
\hline & & $\%$ of Total & $17,6 \%$ & $47,1 \%$ & $29,4 \%$ & $5,9 \%$ & $100,0 \%$ \\
\hline
\end{tabular}

Persentase terbanyak adalah pada tingkat pendidikan SMA. Sedangkan pada subjek dengan PSE rendah persebarannya cenderung merata. Pada tingkat penghasilan, subjek dengan PSE rendah kebanyakan memiliki tingkat penghasilan di bawah satu juta rupiah per bulan (60\% dari PSE rendah). Kebalikannya, subjek dengan PSE sedang kebanyakan $(66,7 \%)$ tingkat penghasilannya antara satu juta dan dua juta rupiah per bulannya. Jika dilihat dari status pernikahan, subjek yang menikah cenderung memiliki PSE sedang (70,6\% dari total subjek), sedangkan $11,8 \%$ subjek yang tidak menikah memiliki PSE rendah. Terakhir menurut tingkat usia Subjek yang memiliki tingkat PSE rendah kebanyakan (60\% dari subjek PSE rendah) berada pada rentang usia 36-40 tahun, sedangkan subjek dengan PSE sedang sebagian besar (50\% dari subjek PSE sedang) berada pada rentang usia 31-35 tahun.

Data hasil kuesioner di atas kemudian didalami oleh peneliti menggunakan wawancara mendalam dan observasi. Lima subjek dari 17 subjek yang mengisi kuesioner di atas berhasil direkrut. Berikut adalah latarbelakang kelima subjek tersebut:

\section{Subjek Pi}

Pi mengalami tuli sebagian (severe loses), dimana ia masih bisa mendengarkan suara-suara dengan volume yang keras (misalnya suara petasan atau orang bicara keras). Pada usia dua tahun Pi mengalami panas tinggi yang mengakibatkan ia tidak lagi bisa mendengar. Pi tampak sebagai pribadi yang ramah dan cerdas. Ia mengungkapkan bahwa pada saat lulus SMU ia memperoleh predikat nilai NEM yang terbaik. Dengan kemampuan kognitif yang baik itu ia menjadi penerjemah bagi teman-temannya sesama peserta pengajian ketika mereka tidak memahami pembicaraan yang dilakukan dengan individu yang berpendengaran normal. Dalam wawancara yang dilakukan pun ia mudah memahami pertanyaan dari pewawancara.

Pi memiliki satu orang anak laki-laki berpendengaran normal yang saat ini berusia 8 tahun. Pi tinggal di rumah orangtua Pi. Hal ini dikarenakan mereka belum mapan secara ekonomi.Sebelumnya Pi diajak tinggal di rumah suaminya, namun ia tidak betah dikarenakan kondisi keluarga suaminya yang serba terbatas dan Pi merasa mertuanya terlalu banyak menuntut dirinya dengan menyuruhnya melakukan pekerjaan rumah yang terlalu banyak. Pada saat anak mereka lahir, Pi sempat mengalami gangguan kesehatan. Ia harus menjalani operasi yang menghabiskan cukup banyak biaya. Orangtua Pi menyalahkan suaminya atas kondisi ini dan meminta suaminya untuk membayar biaya operasi sendiri, tanpa bantuan dari orangtua. Suami Pi yang pada saat itu masih dalam kondisi belum mapan secara ekonomi terpaksa berhutang pada teman sesama peserta pengajian. Dikarenakan orangtua Pi merasa suaminya kurang bisa membiayai 
anaknya, mereka segera meminta Pi kembali tinggal di rumah mereka. Di rumah itu mereka tinggal dengan orangtua dan saudara kandung Pi (seorang kakak dan seorang adik). Setelah tinggal di rumah $\mathrm{Pi}$, hubungan mereka dengan keluarga Pi cukup dekat dan tidak ada masalah yang berarti. Adik kandung $\mathrm{Pi}$ sering mengajak anak mereka (Al) berjalan-jalan, sehingga Al sangat dekat dengan tantenya tersebut.

\section{Subjek Dar}

Dar mengalami ketulian total (profound loses) yang menyebabkan ia tidak dapat mendengarkan suara apapun di sekitarnya meskipun menggunakan alat bantu dengar. Dar mengalami ketulian setelah ia mengalami sakit panas tinggi ketika masih kanak-kanak. Dar memiliki empat orang anak laki-laki berpendengaran normal. Anak pertama mereka berusia 11 tahun, anak kedua berusia 7 tahun, anak ketiga berusia 4 tahun dan yang terakhir berusia 11 bulan. Dar bekerja sebagai buruh pabrik Maspion, sedangkan istrinya Ek adalah seorang ibu rumah tangga.

Pada awal menikah, ia dan istrinya tinggal di rumah kost, kemudian mereka pindah ke rumah orangtua Dar pada saat anak pertama mereka berusia tujuh tahun. Menurut Dar di rumah kos yang dulu, ibu kos mereka sangat baik dan perhatian pada anak mereka. Bahkan ibu kos itu mau belajar bahasa isyarat dan mengajari anak mereka bahasa isyarat agar bisa berbicara dengan Dar dan istrinya. Namun karena kondisi perekonomian yang tidak memungkinkan, mereka kembali ke rumah orangtua Dar. Sayangnya orangtua Dar tidak terlalu peduli pada anak mereka. Ditambah lagi orangtua Dar tidak dapat berbicara dengan bahasa isyarat, sehingga komunikasi dengan mereka kurang lancar.

Menurut Dar istrinya adalah individu yang cerdas dan sabar. Setiap hari istrinya mengurusi anak-anaknya seorang diri tanpa bantuan orangtuanya. Ia mengatakan tidak kesulitan dalam mengatur waktu karena semua sudah dijadwal dengan baik. Setiap hari istrinya bangun sebelum subuh untuk memasak nasi. Setelah Dar bangun, Dar menjaga anak-anak mereka dan istrinya pergi ke pasar untuk berbelanja, kemudian memasak sarapan untuk Dar. Jika Dar bekerja dan istrinya memerlukan sesuatu, anakanaknya dititipkan ke adik kandung Dar.

\section{Subjek NF}

NF mengalami ketulian total (profound loses) sejak kecil setelah mengalami sakit panas tinggi. NF memiliki seorang anak lakilaki berusia empat tahun. Ia dan suaminya sama-sama bekerja di sebuah pabrik di Sidoarjo, sehingga anak mereka diasuh oleh orangtua NF. Kondisi perekonomian orangtua NF termasuk menengah ke atas sehingga dapat membantu menunjang perekonomian keluarga NF. Untuk membantu mengasuh anaknya itu, mereka juga dibantu oleh seorang baby sitter. Pada saat anak pertama mereka duduk di kelas dua SD, NF mengandung anak kedua. Namun pada usia kehamilan dua bulan ia mengalami keguguran. Dokter pun menyatakan bahwa NF harus disterilkan karena kondisi kesehatan jantung NF yang tidak memungkinkan NF untuk memiliki anak kembali. Suaminya yang sangat menginginkan memiliki anak lagi sangat terpukul dengan kondisi tersebut. Berbeda dengan NF yang terlihat lebih tegar menghadapinya.

\section{Subjek NDM}

NDM mengalami ketulian sebagian (severe loses) dimana ia masih bisa mendengar suara-suara dalam volume yang keras. NDM mengalami ketulian sejak usia delapan bulan setelah ia mengalami sakit keras.

NDM memiliki seorang anak 
perempuan yang normal pendengarannya berusia lima tahun. Ia dan suaminya tinggal di rumah mertuanya, namun kedua orangtua suaminya itu sudah tua dan tidak mau tahu dengan urusan keluarga NDM. Saudarasaudaranya juga sudah menikah dan semua sudah pindah dari rumah tersebut kecuali salah satu adik kandung NDM yang belum menikah dan masih sekolah di bangku SMA.

Orangtua NDM sendiri tidak bersedia jika harus membantu NDM dan suaminya mengurus anak. NDM mengaku sejak kecil ia seringkali mengalami penolakan dari orangtuanya sendiri, dikarenakan kondisi pendengarannya. Orangtuanya juga tidak bersedia menyekolahkan NDM ke SMALB karena keterbatasan biaya. Sehingga ketika ia lulus SMP ia langsung dinikahkan dengan suaminya.

\section{Subjek TUH}

TUH mengalami ketulian total (profound loses) sejak ia berusia dua tahun disebabkan sakit panas tinggi. TUH memiliki dua orang anak, laki-laki berusia delapan tahun dan perempuan berusia dua tahun. Anak laki-lakinya lahir dari pernikahannya yang pertama, dan anak perempuannya lahir dari pernikahan yang kedua. TUH menuturkan bahwa pernah menikah dua kali. Pernikahan pertama ia langsungkan dengan pria yang berpendengaran normal. Pernikahan tersebut berakhir dengan perceraian yang dikarenakan karena suaminya mencintai wanita lain dan adanya ketidakharmonisan antara keluarganya dan keluarga mantan suaminya. Kemudian pada saat anak pertamanya berusia lima tahun, ia dilamar oleh mantan teman sekolahnya sesama penyandang tuna rungu yang juga sesama peserta pengajian tuna rungu. Saat ini TUH, suami dan anak keduanya tinggal di Surabaya. Anak pertamanya tinggal di kampung halamannya, Ponorogo, dan diasuh oleh orangtua TUH. Ibu TUH sangat menyayangi cucu pertamanya itu, sehingga ingin merawatnya.

Analisis data hasil wawancara dan observasi menghasilkan beberapa kategori berikut:

\section{Pengalaman langsung}

Faktor pengalaman yang berkaitan dengan parenting self efficacy mencakup bentuk pengasuhan dan pengalaman keberhasilan mengasuh anak. Pada umumnya subjek mengaku kesulitan mengasuh anak dalam hal mengatur perilaku anak yang dirasa mengganggu, misalnya dalam hal penggunaan uang. Mereka tidak dapat memberikan pemahaman pada anak-anak mengenai berbagai hal dikarenakan keterbatasan komunikasi, sehingga mereka lebih cenderung mengikuti kemauan anak. Subjek TUH mengatakan:

"Anakku sering berani ngomong (menentang)
pada orangtua. Contohnya anak sering
meminta uang untuk membeli mainan atau
jajan. Aku melarang anak lalu anak menangis.
Terus aku memberi uang pada anak dan diberi
nasehat jangan mengulangi lagi. Kalau anak
nakal kasih uang jajan biar anak tidak nakal
lagi.".

Demikian halnya dengan subjek Pi yang mengungkapkan:

\begin{abstract}
"Anakku sering sulit dinasehati. Contohnya menangis memaksa minta sepeda baru, diajuga pernah menangis minta tas baru. Kalau sudah menangis aku terpaksa membelikan supaya dia tidaknakal lagi."
\end{abstract}

Selain itu subjek menceritakan ketika anak mereka masih bayi mereka tidak dapat mengontrol kondisi kebisingan di sekitar bayi, padahal bayi sangat responsif terhadap suara ketika mereka tidur. Seperti yang diungkapkan oleh Dar:

"Kalau berisik bayi suka bangun. Aku tidak tahu kalau berisik. Kalau kakaknya ramai aku tidak dengar." 
Kesulitan berkomunikasi ini diatasi dengan meminta bantuan orang terdekat (orangtua, mertua atau pembantu) untuk memberikan nasehat pada anak-anak mereka. Sebagaimana yang diungkapkan NF:

"saya terus kasih uang pembantu untuk ngomong pada anak."

Namun pernyataan dari subjek NDM menunjukkan ia tidak dapat mengatasi kesulitan dalam mengasuh anak:

"Saya susah mengasuh anak. Anak sering meminta uang. Anak juga sering bertengkar, contohnya rebutan sepeda. Anak juga malas. Saya sudah sering nasehat pada anak, tapi anak tidak menurut."

\section{Vicarious experience}

Pengalaman masa lalu berkaitan dengan pengalaman mengamati orang lain melakukan pengasuhan. Semua subjek memiliki tetangga yang mempunyai anak berusia sama dengan anak mereka. Mereka tidak menganggap pengasuhan yang dilakukan tetangga lebih baik daripada pengasuhan yang mereka lakukan. Meskipun menganggap anak memiliki temperamen yang sulit, namun mereka masih menganggap pengasuhan yang dilakukan lebih baik. Seperti yang diungkapkan subjek Dar:

\footnotetext{
"Teman-temannya nakal, suka misuh (berkata kotor), dipukul sama orangtuanya". Demikian halnya subjek TUH yang mengatakan "anakku bagus, tidaknakal. Teman-temannya tidak mau ngaji, orangtuanyacuek".
}

NF menyatakan tidak memiliki kesempatan mengamati orangtua lain dalam mengasuh anak karena ia juga bekerja sampai sore. Hal yang sama juga dilaporkan oleh NDM.

\section{Verbal persuasion}

Verbal persuasion merupakan umpan balik yang diberikan secara verbal oleh orang lain berkaitan dengan pengasuhan yang dilakukan orangtua. Untuk subjek yang mengasuh anak dengan didampingi orangtua (ibu) mereka mendapatkan umpan balik dan informasi dan contoh langsung dari cara-cara yang dilakukan dalam mengasuh anak. Subjek Dar mengatakan:

\section{"Ibu bantu memandikan bayi. Ibu juga sering nasehat (tentang cara mengasuh anak)"}

Bagi subjek yang tidak tinggal dengan orangtua, umpan balik diperoleh dari tetangga atau teman-teman peserta pengajian tunarungu.

Pada umumnya umpan balik yang mereka terima berkaitan dengan pengasuhan nurturance dan material, seperti cara memandikan, bagaimana memenuhi gizi anak, cara merawat anak yang sakit, maupun cara menjaga keamanan dan kenyamanan anak. Namun umpan balik yang diberikan tidak menyangkut penilaian apakah mereka sudah mengasuh anak dengan benar atau belum. Mereka sendirilah yang memberikan penilaian terhadap diri mereka sendiri berdasarkan informasi yang mereka terima dari orang lain.

\section{Emotional State}

Emotional state mencakup kondisi emosional orangtua yang dirasakan ketika sedang mengasuh anak. Pada umumnya kondisi emosi subjek tidak berbeda dengan individu yang normal pendengarannya.Kondisi ketunarunguan yang mereka alami tidak banyak berpengaruh terhadap kondisi emosi mereka. Kondisi emosi subjek pada saat mengasuh anak lebih banyak dipengaruhi oleh karakteristik anak dan 
permasalahan lain yang dialami selain permasalahan pengasuhan, misalnya kondisi sosial ekonomi yang rendah.

Subjek Dar tidak merasa berat dalam melakukan pengasuhan dikarenakan menurutnya anak-anaknya semua sabar dan memahami kondisi orangtuanya yang memiliki kekurangan dalam pendengaran:

"Tak pernah bertengkar (dengan) bapak/ibu. Anak-anak sabar-sabar, (mereka) tahu (dan) kasihan bapak/ibu tuli"'.

Namun hal ini tidak dirasakan oleh subjek lain yang mengaku merasa berat, repot, susah, dan marah. Alasan merasa berat pun beragam, mulai dari kondisi ekonomi yang kurang, anak yang sulit dinasehati, anak yang berani menentang orangtua, maupun tidak adanya pendamping dalam membesarkan anak. Seperti yang diungkapkan Pi:

"Anakku berani sama aku dikarenakan anakku tidak mau tidur siang, sering bermain terus."

\section{Pengalaman Imagery}

Pengalaman imagery yang dimaksud adalah bayangan dan keinginan berkaitan dengan pengasuhan yang ideal menurut diri sendiri. Keinginan yang dimiliki orangtua penyandang tuna rungu sama dengan orangtua pada umumnya. Mereka menginginkan anak mereka lebih bisa menghormati dan menghargai mereka, dan mau mendengarkan mereka. Sebagai orangtua mereka menginginkan lebih banyak waktu dengan anak, dikarenakan hampir semua subjek berprofesi sebagai buruh dengan jam kerja yang panjang, sehingga mereka merasa kurang waktu dengan anak. Selain itu mereka ingin bisa mengajari anak-anak mereka sopan santun (salam sebelum berangkat sekolah, dsb), cara beribadah (sholat), dan keterampilan akademik (belajar dan mengerjakan PR).
Pada subjek Dar keinginan ini juga dipengaruhi harapan-harapan yang dibawa dari masa kecilnya. Ia mengaku ibunya seringkali mengharapkan ia memiliki prestasi yang baik di sekolah, sehingga ia juga memiliki harapan yang sama pada anaknya. Ia berharap bisa lebih banyak mendampingi anaknya dalam belajar, terutama pada pelajaran matematika:

"Ibuku cita-cita pelajar pandai. Aku ingin anak
belajar terus bisa pandai".

\section{Pengalaman Masa Kecil}

Pengalaman masa kecil yang digali melalui wawancara berkaitan dengan bentuk pengasuhan dan pengalaman lain yang dialami semasa kecil. Pengalaman yang paling berpengaruh pada pembentukan keyakinan diri subjek adalah penerimaan dan perlakuan orangtua terkait kondisi subjek yang mengalami keterbatasan komunikasi.

Subjek TUH mengaku seringkali melihat orangtuanya bertengkar. Ia mengungkapkan bahwa orangtuanya memiliki masalah dalam hubungan rumah tangga:

"Aku sering lihat orangtua bertengkar. Perang mulut. Ada masalah rumah tangga."

Namun demikian ia tidak mengetahui apa inti permasalahan yang dihadapi orangtuanya. Meskipun orangtuanya sering bertengkar, TUH mengungkapkan ibunya sangat melindungi dan bahkan cenderung memanjakannya. Lain halnya dengan subjek SUG (suami dari Pi). Ia mengatakan orangtuanya merasa kesulitan dengan kondisi ketunarunguan yang ia alami. Ia mengatakan sering kesulitan berkomunikasi dengan orangtuanya, sehingga orangtuanya merasa susah:

"Ibu tidak mengerti bicara isyarat. Ibu sulit ngomong sama aku. Ibu (merasa) susah". 


\section{Penilaian Diri}

Ketika ditanya secara langsung apakah subjek mampu melakukan pengasuhan dengan baik, hampir semua subjek mengatakan bisa, kecuali subjek NDM. Ia mengatakan masih sulit karena ada sedikit masalah dalam keluarganya. Namun NDM tidak mengungkapkan masalah apa yang ia maksudkan. Ia hanya mengatakan:

"belum bisa. Karena sulit, saya tidak paham. Saya sendirian (dan) masih ada masalah kecil."

\section{Perilaku Pengasuhan}

Analisis perilaku pengasuhan subjek dilakukan berdasarkan data hasil observasi dengan mengacu pada aspek-aspek pengasuhan dari Bornstein (1998). Hasil observasi terhadap empat subjek penelitian dapat dipaparkan sebagai berikut:

\section{Subjek Pi}

Dalam melakukan pengasuhan, Pi dibantu oleh orangtua $\mathrm{Pi}$, terutama dalam aspek nurturant caregiving. Orangtua dan adik Pi banyak membantu dalam pengasuhan. Hal ini sangat membantu bagi $\mathrm{Pi}$, namun efek negatifnya Pi sulit menerapkan aturan yang konsisten pada anak, karena nenek cenderung memenuhi semua keinginan Al. Hal ini menambah kekurangpahaman $\mathrm{Pi}$ tentang pentingnya konsistensi dalam menerapkan aturan di rumah. Hal ini terlihat dalam aspek material caregiving. Pi telah menyediakan permainan dan benda-benda serta kesempatan bermain untuk stimulasi bagi Al, namun ia dan suaminya belum sepakat mengenai aturan waktu dan tempat bermain bagi Al. Dalam hal social caregiving, $\mathrm{Pi}$ dan suaminya memberikan kesempatan Al untuk bersosialisasi dengan orang lain di sekitarnya.
Namun dalam hal pengembangan intrapersonal, Pi jarang mengajak Al bercakapcakap secara pribadi. Selama ini pembicaraan hanya terjadi secara mekanis, yaitu berkaitan dengan pengasuhan nurturant. Dalam hal didactic caregiving, Pi dan SUG memberikan pendidikan moral dan agama dengan bantuan pihak lain (Taman Pendidikan Alquran/TPA).

\section{Subjek Dar}

Dar dan istrinya melakukan nurturant caregiving dengan bantuan ibu mertuanya. Dalam pengasuhan material, Dar dan istrinya telah dapat memastikan keamanan lingkungan anak-anak mereka. Mereka juga menyediakan benda-benda dan kesempatan stimulasi bagi anak. Mereka memberi kesempatan anak untuk bersosialisasi dengan orang-orang yang ada di sekitar mereka. Namun mereka khawatir dengan pengaruh lingkungan yang buruk, terutama pada anak kedua mereka. Mereka tidak tahu cara yang efektif untuk menghentikan perilakunya yang sering bertengkar dan mengucapkan kata-kata kasar dan kotor. Selama ini yang mereka lakukan hanya memarahi dan menasehati jika si anak melakukan hal tersebut. Yang memperburuk keadaan adalah tidak adanya aturan yang konsisten bagi anak-anak mereka, terutama dalam hal disiplin waktu.

Dar telah mengajari anak bagaimana bertanggungjawab terhadap kesalahan mereka, namun mereka masih kesulitan mengajari anak bertanggungjawab pada barang-barang mereka sendiri. Selama ini jika ada perilaku anak yang mengganggu, mereka menggunakan cara mengancam, menasehati, memarahi, mencubit kaki, atau menyentil telinga anak jika anak dirasa sudah keterlaluan. Anak juga jarang diajak bicara karena keterbatasan waktu dan kemampuan anak dianggap belum memadai. Dalam hal didactic caregiving, Dar belum pernah melakukan diskusi dengan anak misalnya 
tentang aturan-aturan yang ada di rumah.

\section{Subjek NF}

Dalam hal nurturant caregiving, pengasuhan NF lebih dominan dilakukan oleh pembantu, karena NF dan suaminya harus bekerja penuh waktu di pabrik. Namun NF tetap berusaha terlibat dalam pengasuhan NF jika ia tidak sedang bekerja. Ia menyatakan bahwa suaminya tidak banyak terlibat secara intensif dalam pengasuhan anaknya. Dalam hal material caregiving, anak diberikan stimulasi yang memadai dan kesempatan untuk bermain dengan teman sebayanya. Namun belum ada aturan yang tetap tentang disiplin waktu bagi anaknya. NF memberi kesempatan anaknya bersosialisasi dengan orang lain di sekitarnya. Anak juga selalu diajak berbincang-bincang tentang pelajaran di sekolahnya. Untuk mengatasi perilaku yang mengganggu, NF melakukan dengan cara mendiamkan anak. Setelah itu anak akan dinasehati oleh orang lain (kakek atau neneknya).

\section{Subjek NDM}

NDM melakukan aspek pengasuhan nurturant tanpa bantuan intensif dari orangtuanya. NDM telah berusaha menjaga keamanan lingkungan bagi anaknya. Ia juga menjelaskan pada anaknya tentang larangan bermain benda yang berbahaya pada anaknya. Di rumah, NDM tidak menyediakan benda stimulasi bagi anaknya, namun ia memberi kesempatan pada anaknya untuk bermain dengan teman-temannya. NDM memberi kesempatan pada anaknya untuk bersosialisasi dengan orang-orang yang ada di lingkungannya. NDM dan suaminya juga sering mengajak anak berbincang-bincang. Jika anaknya melakukan perilaku mengganggu seperti meminta jajan, tidak mau tidur, sering bermain ke rumah tetangga, NDM biasanya menghentikan dengan cara menasehati, mencubit kaki, menjewer telinga, atau memukul kaki anaknya itu.

\section{PEMBAHASAN}

Dari hasil survey dapat dilihat tingkat parenting self efficacy (PSE) pada orangtua tunarungu yang memiliki anak berpendengaran normal sebagian besar berada pada kategori sedang (12 orang), dan sisanya (5 orang) pada kategori rendah. Tidak ada subjek yang memiliki PSE ada kategori tinggi ataupun tinggi sekali. Dari hasil analisis wawancara pembentukan PSE tersebut mengikuti gambar 1 .

\section{Gambar 1. Skema proses pembentukan parenting self efficacy}

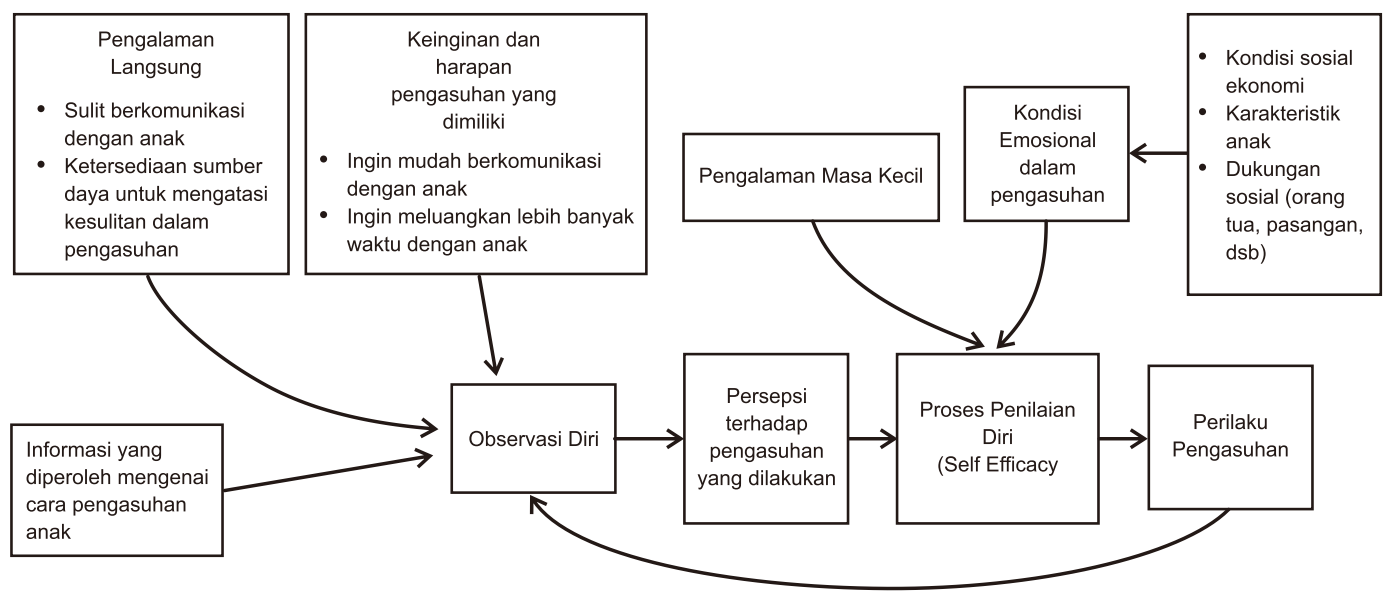


Pada awalnya subjek melakukan observasi diri terhadap pengalaman subjek mengasuh anak. Observasi diri tersebut dipengaruhi kesulitan apa yang dihadapi oleh subjek dalam pengasuhan anak dan kemampuan dirinya dalam mengatasi kesulitan tersebut, baik secara mandiri ataupun dengan bantuan orang lain. Selain itu faktor lain yang berpengaruh terhadap observasi adalah harapan yang dimiliki subjek akan pengasuhan yang baik. Subjek akan membandingkan apa yang sudah ia lakukan dan alami dengan harapan yang ingin ia wujudkan dalam pengasuhan. Selain itu ketersediaan informasi mengenai pengasuhan juga mempengaruhi observasi yang dilakukan subjek. Hasil observasi yang dilakukan subjek akan membentuk persepsi subjek terhadap pengasuhan yang dilakukan.

Secara umum subjek menyatakan bahwa kesulitan yang dialami berkaitan dengan keterbatasan yang mereka miliki dalam berkomunikasi. Banyak hal yang bisa dilakukan oleh orangtua berpendengaran normal yang tidak bisa mereka lakukan. Misalnya subjek NDM mengungkapkan pada saat masih mengandung seringkali ia merasa khawatir bila ia tidur di malam hari ia tidak bisa mendengar ketika bayinya menangis atau membutuhkan sesuatu. Atau bagaimana ia mengajarkan bicara pada anak-anaknya. Subjek NF juga mengungkapkan ia sempat mengkhawatirkan apakah anaknya tuna rungu juga atau tidak, namun ia tidak sampai memeriksakan anaknya ke dokter karena memiliki orangtua dan pembantu yang berpendengaran normal yang dapat memastikan bahwa anaknya bisa mendengar dengan baik. Terkadang subjek juga merasa bodoh karena tidak bisa mengajari anaknya hal-hal yang diajarkan orangtua ketika anaknya berada di TK (Taman Kanak-Kanak), seperti menyanyikan lagu anak-anak atau pelajaran-pelajaran di sekolah yang dirasa cukup sulit bagi mereka, seperti matematika.
Sebagaimana yang diungkapkan oleh American Speech-Language-Hearing Association/ASHA (dalam Heward, 2005), penyandang tunarungu memiliki keterbatasan dalam kosa kata. Mereka lebih mudah mempelajari kata-kata kongkrit dibanding kata-kata abstrak. Hal ini membuat mereka kesulitan dalam membantu anak-anak mereka mempelajari pelajaran yang melibatkan kemampuan abstraksi bahasa maupun ruang dan bidang, seperti matematika atau Pendidikan Kewarganegaraan (PKN).

Dari hasil observasi, subjek yang mendapatkan dukungan sosial dalam hal pengasuhan mempersepsikan pengasuhan yang dilakukan sudah cukup baik jika dibandingkan dengan orang lain, meskipun ia mengalami kesulitan dalam menjalankannya. Berbeda dengan subjek NDM yang harus melakukan pengasuhan tanpa dukungan sosial yang memadai, mengaku bahwa pengasuhan adalah hal yang sulit karena ia tidak memahami apa yang harus ia lakukan, khususnya untuk mengatasi perilaku anak yang mengganggu. Hal ini sejalan dengan penelitian LeahyWarren dkk. (2011) yang menunjukkan bahwa terdapat hubungan yang signifikan antara dukungan sosial yang diterima dari keluarga dan teman dengan tingkat PSE. Lebih lanjut Jones \& Prinz (2005) menyatakan bahwa dukungan yang diterima tersebut dapat meningkatkan PSE. Leahy-Warren dkk. (2011) menambahkan dukungan yang diterima dari ibu kandung lebih banyak menyumbang pada peningkatan PSE. Dukungan dari ibu kandung dapat meningkatkan PSE melalui pengalaman mengenai pengasuhan anak dan dukungan verbal, sehingga pada orangtua yang memiliki dukungan dari ibu kandung akan sangat terbantu dalam melakukan pengasuhan. Selanjutnya Teti and Gefland (1991) menunjukkan bahwa PSE yang tinggi berhubungan positif dengan dukungan yang diperoleh dari pernikahan. Orangtua yang memiliki dukungan yang konsisten dari figur 
intim akan memiliki self efficacy yang lebih baik dan pada gilirannya akan melakukan pengasuhan dengan lebih efektif. Hal ini konsisten dengan hasil tabulasi silang dimana orangtua yang bercerai cenderung memiliki tingkat PSE yang rendah.

Tidak hanya persepsi terhadap pengasuhan saja, namun juga pengalaman masa kecil dan kondisi emosional yang mempengaruhi pembentukan PSE subjek. Kondisi emosional pada orangtua tuna rungu pada dasarnya tidak berbeda dengan individu berpendengaran normal. Dari hasil wawancara ada tiga faktor utama yang berpengaruh pada kondisi emosional orangtua tuna rungu, yaitu kondisi sosial ekonomi, karakteristik anak, dan, sekali lagi, persepsi subjek tentang ketersediaan dukungan sosial dalam pengasuhan. Hal ini terlihat dari pernyataan subjek mengenai kesulitan yang dihadapi saat mengasuh anak. Kebanyakan subjek mengatakan merasa susah jika anak meminta uang atau minta dibelikan berbagai benda dan mereka tidak mampu menyanggupinya. Subjek Pi bahkan mengatakan pernah bertengkar dengan anaknya karena anaknya memaksa minta dibelikan sepeda baru, sementara ia tidak memiliki cukup uang. Sama halnya dengan subjek NDM yang mengaku bingung jika anaknya terus menerus meminta uang untuk membeli jajanan. Namun jika melihat pernyataan subjek Dar, kondisi ekonomi yang kurang mendukung tidak menjadi masalah jika orangtua mempersepsikan karakteristik anak dengan positif. Berbeda dengan subjek NF yang memiliki kondisi ekonomi sama dengan Pi namun tetap mendapatkan bantuan intensif dari orangtuanya, ia cenderung lebih fokus pada kesulitan dalam mendisiplinkan anak, seperti menyuruh anak tidur siang atau mengatur jadwal bermain anak. Ia mengatakan merasa jengkel jika anaknya sulit disuruh tidur dan tidak mau pulang ketika bermain dengan teman-temannya.
Penilaian diri yang dilakukan subjek mempengaruhi secara langsung perilaku pengasuhan yang dilakukan. Hal ini sesuai dengan pernyataan Jones dan Prinz (2005) bahwa individu dengan PSE tinggi yakin dengan kemampuannya untuk mendapatkan dan menerapkan keterampilan keorangtuaan yang efektif, sehingga membawa pada tingkat kompetensi keorangtuaan yang tinggi pula. Sebaliknya individu yang memiliki tingkat PSE rendah tidak akan berusaha untuk mencari informasi mengenai keterampilan keorangtuaan yang efektif, karena mereka telah meyakini bahwa mereka tidak bisa menguasai keterampilan tersebut.

Berdasarkan hasil wawancara, dapat disimpulkan bahwa ada dua aspek pengasuhan yang dapat dilakukan subjek tanpa kesulitan, yaitu nurturant dan material caregiving. Subjek melaksanakan nurturant caregiving dengan sedikit bantuan dari orangtua, saudara kandung, ataupun pembantu. Subjek melakukan material caregiving dengan cara memastikan keamanan lingkungan anak, memberikan permainan yang dapat menstimulasi anak dan kesempatan bermain dengan teman sebayanya dan menyediakan waktu bermain bagi anak. Social caregiving dilakukan sebatas memberikan kesempatan anak bersosialisasi dengan lingkungan sekitarnya. Namun subjek belum memahami cara memberikan respon yang positif atas ekspresi emosi anak. Subjek kurang memahami pentingnya respon orangtua dalam pembentukan perilaku anak. Hal ini terlihat dari hasil wawancara dimana mereka lebih menekankan pada perilaku negatif anak dan kurang memberikan penguat pada perilaku positif anak. Subjek juga kurang memahami cara efektif untuk menghentikan perilaku anak yang mengganggu. Hal ini terlihat dari hasil wawancara dimana mereka memiliki kecenderungan menggunakan kekerasan fisik dan menasehati untuk mengurangi perilaku 
yang mengganggu. Mereka juga dapat melakukan aspek didactic caregiving untuk hal-hal yang bersifat fisik dan kongkrit, seperti rutinitas sehari-hari, mengajarkan halhal yang dapat diterima oleh masyaraka, dan sebagainya. Namun untuk hal-hal yang bersifat abstrak seperti mengajarkan nilainilai dan makna dari berbagai hal dalam kehidupan tidak dapat mereka lakukan.

Pada gilirannya, orangtua akan kembali mengobservasi perilaku pengasuhan yang dilakukan dan akan mempengaruhi pembentukan PSE mereka. Sebagaimana yang diungkapkan oleh Jones \& Prinz (2005) bahwa PSE merupakan variabel transaksional dimana orangtua dengan tingkat PSE tinggi akan memperoleh kepuasan yang besar dari perilaku pengasuhan mereka, yang akan mengarah pada berlanjutnya perilaku pengasuhan yang efektif, dan dengan demikian akan meningkatkan kecenderungan untuk menghasilkan perilaku positif pada anak. Perilaku positif tersebut akan meningkatkan PSE orangtua. Seiring dengan hal tersebut, orangtua dengan tingkat PSE yang rendah akan mengalami tingkat frustasi yang tinggi, menimbulkan masalah perilaku pada anak serta perilaku yang buruk yang kemudian menurunkan tingkat PSE mereka.

\section{SIMPULAN}

Dari hasil penelitian ini diperoleh kesimpulan bahwa kondisi parenting self efficacy (PSE) yang dimiliki oleh orangtua tunarungu yang memiliki anak berpendengaran normal berada pada kategori sedang, dan banyak dipengaruhi oleh keterbatasan yang mereka miliki. Hal yang paling berpengaruh pada tingkat PSE mereka adalah ketersediaan dukungan sosial yang dapat membantu mereka mengatasi kesulitan dan memberikan informasi pada mereka seputar pengasuhan anak. Ketersediaan dukungan sosial tersebut tidak hanya mempengaruhi persepsi mereka terhadap pengalaman pengasuhan yang mereka alami, namun juga mempengaruhi kondisi emosional mereka dalam proses pengasuhan anak.

Implikasi dari penelitian ini adalah pemahaman mengenai proses kognisi pada penyandang tuna rungu terutama dalam hal pengasuhan anak. Hal ini dapat membantu pihak-pihak yang berkepentingan dengan pengembangan pendidikan bagi penyandang tunarungu maupun program keorangtuaan secara umum.

\section{SARAN}

Mengingat subjek dalam penelitian ini sangat terbatas jumlahnya maka disarankan untuk melakukan penelitian lanjutan dengan jumlah subjek yang lebih banyak untuk mendapatkan pemahaman yang lebih luas dan mendalam. Bagi peneliti selanjutnya yang ingin meneliti mengenai subjek tunarungu sebaiknya merumuskan alat ukur dengan bahasa sekongkrit mungkin disertai contohcontoh yang mudah ditemui dalam kehidupan subjek sehari-hari. Hal ini dikarenakan keterbatasan kosa kata yang dimiliki subjek, sehingga tanpa penerjemah penelitian akan sulit dilakukan. Disarankan juga meneliti lebih lanjut mengenai pengalaman pengasuhan dari perspektif anak-anak yang memiliki orangtua penyandang tunarungu.

\section{DAFTAR PUSTAKA}

Bandura, A. (1994). Self-efficacy. Dalam R. J. Corsini (Ed.), Encyclopedia of psychology (2nd ed., Vol. 3, pp. 368-9). New York: Wiley.
Bandura, A. (1977). Self-Efficacy : Toward a Unifying Theory of Behavioral Change. Psychological Review, 84, 2, 191-215. 
Bigner, J. J. (1994). Parent-Child Relations : an Introduction to Parenting, $4^{\text {th }}$ edition. New Jersey: Prentice Hall.

Bornstein, M. H. (1998). Refocusing on Parenting. Diakses dari . pada tanggal 2 Mei 2013

Coleman, P. K. \& Karraker, K. H. (2000). Parenting Self-Efficacy Among Mothers of School Age Children: Conceptualization, Measurement, and Correlates. Diakses dari http://www.jstor.org/stable/585698 pada tanggal 26 Februari 2013.

Coleman, P. K. (1998). Maternal Self-Efficacy Beliefs as a Predictors of Parenting Competence and Toddlers Emotional, Social, and Cognitive Development. (Dissertation). Diakses dari . pada tanggal 6 juli 2013.

Direktorat Pendidikan Luar Biasa Departemen Pendidikan Nasional. (2004). Alat Identifikasi Anak Berkebutuhan Khusus. Jakarta: Direktorat PLB Departemen Pendidikan Nasional.

Donovan, W. L., Leavitt, L. A., \& Walsh, R. O. (1997). Cognitive set and coping strategy affect mothers' sensitivity to infant cries: A signal detection approach. Child Development, 68, 760-772.

Harty, M. (2009). The Validation of a task-specific Measure of a Parenting Self-efficacy for Use With Mothers of Young Children.
Diakses dari pada tanggal 1 Juli 2013.

Heward, W. L. (2003). Exceptional Children : An Introduction to Special Education. New Jersey : Merrill Prentice Hall.

Jacobson, A. L. (2004). Contemporary Models for Positive Parenting. Journal of Family and Consumer Sciences, 96, 4-9.

Jones, T. L. \& Prinz, R. J. (2005). Potential Roles of Parental Self Efficacy in Parent and Child Adjustment : A review. Clinical Psychology Review, 25, 341-363

Leahy-Warren, P, McCarthy, G., \& Corcoran, P. (2011). First-time mothers: social support, maternal parental self-efficacy and postnatal depression. Journal of Clinical Nursing, 21 (3-4),388-397. Diakses dari: www.nsrf.ie/publications_2011/First_time _Mothers.pdf, pada tanggal 1 Juli 2013.

Sanders, M. R. \& Woolley, M. L. (2005). The relationship between maternal self-efficacy and parenting practices: implications for parent training. Child: Care, Health and Development, 31 (1), 65-73.

Shahan, C. L. (2003). Marriages and Families, $2^{\text {nd }}$ edition. Boston: Allyn and Bacon.

Teti, D. \& Gelfand, D. (1991). Behavioural competence among mothers of infants in the first year: the mediational role of selfefficacy. Child Development, 65, 918-929. 